\title{
Responses to the 2018 and 2019 'One Big Discovery' Question: ASTRO membership's opinions on the most important research question facing radiation oncology... where are we headed?
}

Michael M. Dominello, Tim Sanders, Mitchell Anscher, John Bayouth, Kristy K. Brock, David J. Carlson, Geoffrey Hugo, Sabrina Joseph, Jonathan Knisely, Marc S. Mendonca, Omar Y. Mian, Eduardo G. Moros, Anurag K. Singh, James B. Yu

This is the author's manuscript of the article published in final edited form as:

Dominello, M. M., Sanders, T., Anscher, M., Bayouth, J., Brock, K. K., Carlson, D. J., Hugo, G., Joseph, S., Knisely, J., Mendonca, M. S., Mian, O. Y., Moros, E. G., Singh, A. K., \& Yu, J. B. (2020). Responses to the 2018 and 2019 "One Big Discovery" Question: ASTRO Membership's Opinions on the Most Important Research Question Facing Radiation Oncology...Where Are We Headed? International Journal of Radiation Oncology, Biology, Physics. https://doi.org/10.1016/j.jirobp.2020.08.032 
At ASTRO's 2017 Annual Meeting in San Diego, CA, attendees were asked for the first time, "What is the most important research question that needs to be answered in the next 3-5 years?" This request was meant to start a dialogue, promote thoughtful discussion within our professional community, and help inform topics for ASTRO workshops and focus meetings. There were nearly 550 responses in 2017 with the top 5 as follows: Immunotherapy/radiotherapy combination, genomic influences and targeted medicine, new clinical trial design, advanced imaging, and oligometastatic disease. In the subsequent years, ASTRO used these results to help guide future direction in several ways including forming think tanks and developing workshops. Think tanks were dedicated to biomarkers and nanotechnology in radiation oncology, the promises and pitfalls of genetic testing, and another on the genetic determinants in radiation oncology. Subsequent ASTRO Research Workshops deliberated the role of the tumor microenvironment, the influence of radiation on the immune response, and treatment of oligometastatic disease, highlighting the biology, clinical trials, and advances in imaging and physics relevant to the management of oligometastatic disease.

During ASTRO's two subsequent meetings (2018, San Antonio and 2019, Chicago), attendees were asked yet again, "What is the One Big Discovery that needs to be translated into the clinic RIGHT NOW?" Responses were quite varied, from "the increasing role of liquid biopsies," to "enrolling in RO-ILS and enhancing our culture of safety," to "Ultra-High Dose Rate (FLASH) Radiotherapy...is it real or not?" Averaging over the two years, approximately half of respondents were academic while half were in private practice. There were 2.5 times more male respondents than female (71\% vs. $29 \%$ ) and most respondents practice domestically (90\% vs. 10\%). Millenials represented just $15 \%$ of respondents while Generation X and Baby Boomers were responsible for submitting the majority of responses, $48 \%$ and $35 \%$ respectively; for 
breakdown by year see Table 1. With 677 responses in 2018, the top 5 were: Immunotherapy (19\%), Treatment for oligometastases (15\%), SBRT (11\%), Hypofractionation (6\%), and Liquid Biopsies (3\%). In 2019 there were 730 responses, the top 5 of which were: FLASH (15\%), Immunotherapy (12\%), SBRT (5\%), Enhanced data (3\%), and Treatment for oligometastases (3\%). The most frequently referenced cancer treatment sites in the 2017 initial survey were prostate and breast; interestingly this finding persisted in 2018 and 2019 as well. In 2018 all age groups ranked immunotherapy first but 1 year later Millennial and Generation X respondents now ranked FLASH radiotherapy first while Baby Boomers stood fast with immunotherapy.

And so, what is the One Big Discovery that needs to be translated into the clinic RIGHT NOW? In an attempt at synthesizing the spirit behind the top choices from 2018 and 2019, it seems that our membership continues to see significant value in radiation therapy (be it hypofractionated or stereotactic ablative) as a tool that can be increasingly utilized to target disease in patients with metastatic or limited metastatic disease and the potential of new delivery techniques like FLASH. Given the ongoing positive response, and the informative variation in trends from year to year, we will ask this question yet again at the 2020 Annual Meeting via virtual platform except with separate radiobiology, physics, and clinical components:

1) What is the 1 Big Radiobiology Discovery that needs to be translated into clinic care RIGHT NOW?

2) What is the 1 Big Medical Physics Discovery that needs to be translated into clinical care RIGHT NOW? 
3) What is the 1 Big Clinical Discovery that needs to be translated into clinical care RIGHT NOW?

We look forward to hearing from you. Stay tuned and thank you for your contribution! 


\begin{tabular}{|c|c|c|c|c|}
\hline Demographics & \multicolumn{2}{|c|}{$2018^{a}$} & \multicolumn{2}{|c|}{$2019^{b}$} \\
\hline Practice Location & $\begin{array}{l}\text { Respondents } \\
(n=675)\end{array}$ & $\begin{array}{l}\text { Membership }(n= \\
\text { 7097) }\end{array}$ & $\begin{array}{l}\text { Respondents } \\
(n=725)\end{array}$ & $\begin{array}{l}\text { Membership } \\
(n=7385)\end{array}$ \\
\hline Hospital-based & $70 \%$ & $74 \%$ & $73 \%$ & $75 \%$ \\
\hline Freestanding/Satellite clinic & $24 \%$ & $23 \%$ & $22 \%$ & $22 \%$ \\
\hline $\begin{array}{l}\text { I practice less than three days } \\
\text { a week }\end{array}$ & $3 \%$ & $2 \%$ & $3 \%$ & $2 \%$ \\
\hline Commercial entity & $3 \%$ & $1 \%$ & $2 \%$ & $1 \%$ \\
\hline Primary Employer & $\begin{array}{c}\text { Respondents } \\
(n=676)\end{array}$ & $\begin{array}{c}\text { Membership }(n= \\
6903)\end{array}$ & $\begin{array}{c}\text { Respondents } \\
(n=727)\end{array}$ & $\begin{array}{l}\text { Membership } \\
(n=7231)\end{array}$ \\
\hline Academic/University system & $42 \%$ & $46 \%$ & $42 \%$ & $49 \%$ \\
\hline $\begin{array}{l}\text { Private practice/Community- } \\
\text { based system }\end{array}$ & $42 \%$ & $43 \%$ & $43 \%$ & $41 \%$ \\
\hline Government/Public sector & $8 \%$ & $6 \%$ & $8 \%$ & $6 \%$ \\
\hline $\begin{array}{l}\text { Independent } \\
\text { contractor/Locum tenens }\end{array}$ & $4 \%$ & $3 \%$ & $3 \%$ & $2 \%$ \\
\hline Industry & $2 \%$ & $1 \%$ & $3 \%$ & $1 \%$ \\
\hline $\begin{array}{l}\text { My employer doesn't fall on } \\
\text { this list }\end{array}$ & $2 \%$ & $1 \%$ & $1 \%$ & $1 \%$ \\
\hline Domestic vs. International & $\begin{array}{l}\text { Respondents } \\
(n=622)\end{array}$ & $\begin{array}{l}\text { Membership } \\
(\mathrm{n}=8419)\end{array}$ & $\begin{array}{c}\text { Respondents } \\
(n=523)\end{array}$ & $\begin{array}{l}\text { Membership } \\
(n=8243)\end{array}$ \\
\hline Domestic & $94 \%$ & $76 \%$ & $86 \%$ & $75 \%$ \\
\hline International & $6 \%$ & $24 \%$ & $14 \%$ & $25 \%$ \\
\hline US Region & $\begin{array}{c}\text { Respondents } \\
(n=561)\end{array}$ & $\begin{array}{l}\text { Membership } \\
(\mathrm{n}=6324)\end{array}$ & $\begin{array}{c}\begin{array}{c}\text { Respondents } \\
(n=447)\end{array} \\
\end{array}$ & $\begin{array}{c}\text { Membership } \\
(\mathrm{n}=6190)\end{array}$ \\
\hline South & $30 \%$ & $33 \%$ & $26 \%$ & $35 \%$ \\
\hline Northeast & $25 \%$ & $22 \%$ & $28 \%$ & $22 \%$ \\
\hline West & $25 \%$ & $22 \%$ & $19 \%$ & $21 \%$ \\
\hline Midwest & $20 \%$ & $23 \%$ & $27 \%$ & $22 \%$ \\
\hline Gender & $\begin{array}{l}\text { Respondents } \\
(n=494)\end{array}$ & $\begin{array}{l}\text { Membership } \\
(\mathrm{n}=6881)\end{array}$ & $\begin{array}{l}\text { Respondents } \\
(n=407)\end{array}$ & $\begin{array}{l}\text { Membership } \\
(n=6641)\end{array}$ \\
\hline Male & $73 \%$ & $69 \%$ & $69 \%$ & $70 \%$ \\
\hline Female & $27 \%$ & $31 \%$ & $31 \%$ & $30 \%$ \\
\hline Generation & $\begin{array}{l}\text { Respondents } \\
(n=221)\end{array}$ & $\begin{array}{l}\text { Membership } \\
(\mathrm{n}=7660)\end{array}$ & $\begin{array}{l}\text { Respondents } \\
(n=443)\end{array}$ & $\begin{array}{l}\text { Membership } \\
(n=7015)\end{array}$ \\
\hline Millennial, 1981-1996 & $14 \%$ & $19 \%$ & $16 \%$ & $24 \%$ \\
\hline Gen X, 1965-1980 & $46 \%$ & $41 \%$ & $49 \%$ & $40 \%$ \\
\hline Baby Boomers, 1946-1964 & $36 \%$ & $38 \%$ & $34 \%$ & $35 \%$ \\
\hline Silent, 1945 or earlier & $5 \%$ & $2 \%$ & $1 \%$ & $2 \%$ \\
\hline
\end{tabular}

a 2018 Sampling frames: Respondents $n=677$; ASTRO Membership Survey $n=8427$

${ }^{\mathrm{b}} 2019$ Sampling frames: Respondents $n=730$; ASTRO Membership Survey $n=8292$ 